\section{Revista Brasileira de Administração Científica}

Brazilian Journal of Scientific Administration

Abr a Jun 2020 - v.11 - n.2
RBADM

ISSN: 2179-684X

\title{
The importance of personal marketing for veterinary acting in the pet Market
}

The pet sector is constantly expanding in Brazil, is among the largest world markets in the area. This work aims to highlight the importance of the study and knowledge of current techniques of personal marketing and their application in the practice of veterinary medicine, emphasizing the professionals working in the pet segment. Although the Veterinarian is a great value added to the pet market, these professionals are not commonly concerned with marketing strategies, as they often did not have contact with the theme even during graduation. Considering the change in pet owner's behavior who often treat the pet as a family member and the current competitiveness of the veterinary market, marketing techniques, when used correctly, are important tools for visibility and differentiation of the professional in the market.

Keywords: Marketing; Veterinary Medicine; Pet Market; Entrepreneurship.

\section{A importância do marketing pessoal para o médico veterinário atuante no mercado pet}

\begin{abstract}
O setor pet encontra-se em constante expansão no Brasil, estando entre os maiores mercados mundiais da área. O presente trabalho tem como objetivo destacar a importância do estudo e conhecimento das técnicas atuais de marketing pessoal e sua aplicação no exercício da medicina veterinária, dando ênfase aos profissionais que atuam no segmento pet. Apesar do Médico Veterinário ser um grande agregador de valor ao mercado pet, não se observa comumente a preocupação desses profissionais com estratégias de marketing, já que muitas vezes não tiveram contato com o tema nem durante a graduação. Considerando-se a mudança de comportamento dos donos de pets que, muitas vezes, tratam o animal com membro da família e a atual competitividade do mercado veterinário, as técnicas de marketing, quando utilizadas de forma correta, são importantes ferramentas para a visibilidade e diferenciação do profissional no mercado.
\end{abstract}

Palavras-chave: Marketing; Medicina Veterinária; Mercado pet; Empreendedorismo.

Topic: Marketing e Estratégias Mercadológicas

Reviewed anonymously in the process of blind peer.
Received: 15/03/2020

Approved: 02/04/2020
Adriana Leão de Carvalho Lima Gondim (iD

Universidade Federal Rural de Pernambuco, Brasil

http://lattes.cnpq.br/7197256086560578

http://orcid.org/0000-0003-2931-8162

adrianalclg@gmail.com

Caio Julio Cesar de Campos Braga Sousa Gondim (D)

Universidade dos Guararapes, Brasil

http://lattes.cnpq.br/4254692337296781

http://orcid.org/0000-0002-0858-2290

gondim.caio@gmail.com

Igor de Lima Macêdo (iD

Universidade dos Guararapes, Brasil

http://lattes.cnpq.br/2439037042472207

http://orcid.org/0000-0002-5599-3180

igor.macedo097@gmail.com

\author{
Raquel Maria de Azevêdo (iD \\ Universidade dos Guararapes, Brasil \\ http://lattes.cnpq.br/1493071642029844 \\ http://orcid.org/0000-0002-2886-704X \\ azevedo raquel 97@hotmail.com
}

Referencing this:

GONDIM, A. L. C. L.; GONDIM, C. J. C. C. B. S.; MACÊDO, I. L.; AZEVÊDO, R. M.. The importance of personal marketing for veterinary acting in the pet market. Revista Brasileira de Administração Científica, v.11, n.2, p.10-23, 2020. DOI: http://doi.org/10.6008/CBPC2179$684 X .2020 .002 .0002$ 


\section{INTRODUCTION}

Marketing is a tool that has been used and taught since ancient times, becoming a twentieth-century academic discipline at American universities (SHAW, 2005; POLIZEL et al., 2019). After this introduction, marketing has undergone numerous transformations throughout history, mainly related to definitions, concepts, thoughts, business philosophies, and market behavior (KOTLER, 2000; VARGO, 2004; POLIZEL et al., 2019). In the 1950s, there were still no marketers in Brazil. Salespeople were part of the commercial departments of the companies (COBRA, 2005).

Marketing came to Brazil in 1954 through the Getulio Vargas Foundation School of Business Administration in São Paulo, where it became known in the business market and was used by business people, not always properly, as an advertising tool (SANTOS et al., 2016). According to Cobra (2005), since the foundation of the School of Business Administration by such a foundation, marketing is no longer just a curricular component but has management status in industrial and commercial organizations. It was around 1975 that it began to be broadly incorporated by companies, emerging professionals in their structures, as well as the effort to create training courses in this area to meet the needs of companies (COBRA, 1997). In the nineties, using technology, marketing took a different position, making use of communication tools such as direct marketing and the Internet, in an attempt to attract customers and generate superior value to marketed products (LIMEIRA, 2004). Marketing as a marketing tool is constantly evolving and adapting to the current reality of the market and especially of society (FLOSI, 2001).

For Zaltman (1987), "marketing is a technique of exchange between people or groups," whereas for Kotler (2006), marketing "is a social process whereby people and groups of people get what they need and desire by creating, offering and freely negotiating valuable products and services with others". Today, modern society is living in the information age, a key element for business success and market adaptation. Thus marketing can be seen as "the art of discovering opportunities, developing them and profiting from them" (KOTLER, 2000). In 2008, the American Marketing Association conceptualized marketing as the activity, set of institutions, and processes used to create, communicate, distribute, and exchange offers that have value to consumers, customers, partners, and societies as a whole (SANTOS et al., 2016). Also according to Kotler (2002), “(...), the goal of Marketing is to make selling superfluous. The goal is to know and understand the customer so well that the product or service suits them and sells itself. "

Personal Marketing is an offshoot of Marketing and emerges as a tool to achieve professional success, as it encompasses image care (KOTLER, 2002). Personal marketing is a new discipline that uses the concepts and instruments of marketing for the benefit of the career and personal experiences of individuals, valuing the human being in all its attributes, characteristics and complex structure (KOTLER, 2000). According to Penteado Filho (1990), successful marketing begins with personal marketing, through which the professional should equate their particular difficulties seeking the proper way to organize and only then should focus on strategic planning.

Today, the veterinarian is beginning to recognize himself as part of a chain in which his knowledge is 
essential to influence a buying and selling process (GIOSO, 2007). Veterinary marketing represents an opening of new horizons and perspectives in the labor market, together with the satisfaction of needs and desires through the exchange process (FLOSI, 2001).

During college, the student's primary focus is clinical, surgery, therapy, but knowledge about planning, administration, organization, auditing and even work ethic is not widespread (FLOSI, 2001). Many of the new veterinarians entering the job market have had no contact with marketing during graduation, and over time realize that this tool is indispensable for success, regardless of their area of expertise (POLIZEL et al., 2019).

When applying the concept of marketing within veterinary medicine, we should consider primarily the management of establishments such as clinics and hospitals, personal marketing by the clinician, internal marketing, customer relationships, fixed and operating costs with other staff, plan marketing actions, perform market actions, and lastly, be up to date on the legislation that regulates the practice of veterinary activity (FLOSI, 2001). Such a concept seems to have been little explored by professionals in the field until the present day (POLIZEL et al., 2019).

The pet products and services market is gaining worldwide prominence and is characterized as a new and profitable segment of the economy (FLOSI, 2001; FARACO, 2004; DINIZ, 2005; GIOSO, 2007; POLIZEL, 2019). The increased affection manifested in relation to pets partly explains the growth in the consumption of these products and services, further stimulating their expansion (GIOSO, 2007). Customers are increasingly demanding, making the market more competitive and seeking professionals who are informed and able to offer excellent services, good relationships, technology, and differentiated services. Analyzing this fact, the professional must seek knowledge about marketing concepts and their application in the current scenario (POLIZEL et al., 2019). Market evolution sophisticates the pet owner's expectations for pet services and products. This requires the veterinarian in addition to professional technique, market knowledge, administrative management and entrepreneurship while working in the commercial or clinical area (GIOSO, 2007).

With the current increase in the number of veterinary establishments, the challenge becomes good management in relation to the public (POLIZEL et al., 2019). According to Kotler (2000), the public is defined as a group that has a potential interest or impacts the ability of a company to achieve its objectives. Services, on the other hand, are activities that create value and generate benefits for customers (LOVELOCK et al., 2005). In the case of veterinary clinics, the public is pet owners purchasing veterinary products and services. (POLIZEL et al., 2019). Professional services are performed by professionals with specific technical training, where their performance is under the norms established in codes of ethical conduct (KOTLER, 2000).

According to Flosi (2001), "marketing for veterinary clinics and hospitals is related to animal health and welfare, where professionals provide quality services, and owners who seek them, seek services related to animal health and welfare, a relationship of supply, demand, and customers".

The main objective of the professional is to make the business profitable, whether in the clinical area, hospital or even autonomous activity, but its biggest challenge is in relation to managerial capacity, together 
with technical capacity, always respecting professional ethics (POLIZEL et al., 2019). Marketing planning is an administrative resource that helps maintain and increase the fit between business resources and objectives and market opportunities (SANDHUSEN, 2003). Through marketing planning, it is possible to make better decisions about the future of the enterprise, as it becomes better known what should happen, and it is possible to more easily predict the outcome of the decisions made (SARQUIS, 2003). This type of planning is very important for any professional or business to achieve its goals (KOTLER, 2000). For the veterinarian who is a service provider, personal marketing is very similar to corporate marketing, but in this case what is being created is a personal brand (ROGAR, 2007).

\section{METHODOLOGY}

This article was elaborated through bibliographical research on the subject, seeking, firstly, to define what marketing is, to analyze the importance of its application in veterinary medicine, with emphasis on the pet market. Bibliographic research is developed trying to explain a problem from the theories published in several types of sources: books, articles, manuals, encyclopedias, annals, electronic media, among others. The accomplishment of bibliographical research is fundamental to know and analyze the main theoretical contributions of a certain theme or subject.

Koche (1997) states that "bibliographic research can be performed for different purposes: to broaden the degree of knowledge in a particular area, enabling the researcher to better understand or delimit a research problem".

The bibliographic research, therefore, has the purpose of exploring problems from theoretical assumptions about the approach of the subject in scientific research, so that this reference "is not a mere repetition of what has already been said or written about a certain subject, but provides the examination of a theme under a new focus or approach, reaching innovative conclusions". (MARCONI et al., 2002).

Diehl et al. (2006) state that "bibliographic research is developed from already elaborated material, based mainly on books and scientific articles and among its advantages is the fact that documents constitute a large and stable source of data". According to Lakatos et al. (2010), "the purpose of bibliographic research is to form a direct contact of the researcher with everything that has been written and made available through various means on the subject".

For this article, the bibliographic study was developed through research mainly in books, journals and other articles on the subject, seeking to gather important information about the change in society's behavior regarding pets, the expansion of the pet market in Brazil, and how knowledge and application of marketing techniques in veterinary medicine can contribute to the differentiation of professionals working in the area and consequent increase of their visibility and profitability.

\section{THEORETICAL DISCUSSION}

The role of the veterinarian in the humanization of pets and the consequent expansion of the pet market

The relationship between man and domestic animals dates back thousands of years (FUCK et al., 
2006). The term pet is an expression of the English language commonly used by sales, marketing and media to refer to pets, which are those inserted in the family environment, generating benefits from the affective relationships established with them (ELIZEIRE, 2013). Another thing to consider is that these animals also represent a growing market. The growth of the small animal products and services market, the so-called "pet" market is confirmed by checking the commercial data involved in the segment (FARACO, et al., 2004).

The pet market has achieved significant growth in recent decades. Consumers are looking for products and services that give their pets a better quality of life (DINIZ, 2005). Elizeire (2013) points out that this close relationship favors the pet market by raising the standard of pet consumption.

One factor that has contributed to the expansion of veterinary services is the current family structure, where today's families are smaller, and opting for pets. This demand also increases the number of veterinary clinics, consequently presenting a saturation and competition in the market (POLIZEL et al., 2019). Today, the number of dogs and cats as pets is growing, supporting the idea that human life, shared with animals, is instituted as a new form of existence (ANDERLINE et al., 2007). More and more animals are considered family members, and even substitutes for children and other family members causing a growing phenomenon of anthropomorphizing dogs and cats in society (YOUNG, 1987).

For Hagiwara (2015), due to this social movement, there is a need for a perception of change in society and Veterinary Medicine undergraduate courses are forming extremely technical professionals, lacking the humanistic training of the professional, and this perception is coming very slowly to veterinarians working in the field.

The veterinarian must have the ability to say "that's it" and be convincing. For the family of the animal is an affective matter. Owners often pay more attention to animals than their children. Given the existence of this new social configuration in the human-animal relationship, there is a need to re-signify the interspecies bond in Veterinary Medicine, when veterinary practice should be centered on the relationship of people with their animals and not focused on the isolated animal and specifically. (TATIBANA et al., 2009).

These professionals play an important role as educators, and they should clarify the necessary management care, animal welfare conditions and the basic principles of the biology of each species (ANDERLINE et al., 2007). The veterinarian must make a difference, he cannot diagnose the disease, treat it and the patient left behind (HAGIWARA, 2015). Recognizing this link between man and companion animals, we note the important role of the Veterinarian as a mediator and equilibrium promoter of this interaction (TATIBANA et al., 2009).

The area's labor market is expanding and spreading through various other branches of veterinary medicine, removing the stereotype that the veterinary professional is the pet doctor, but the small animal clinic is recognized as one of the most important. Among these, mainly by the greater contact established between the professional and the owner, thus forming a pleasant state of empathy with society (SOUZA, 1996; TATIBANA et al., 2009). Hagiwara (2015) conducted a study on the nature of ethical processes presented to the São Paulo Council of Veterinary Medicine, it was observed that, currently, the failures in the care of veterinary doctors who work with pets involve psychological and posture issues in the care of a specific public. In that study, it was found that over $90 \%$ of the complaints presented are related to the care 
of small animals. Thus, it was concluded that the communication between the veterinarian and the owner is not receiving the proper attention and the professional must be aware and adapt to the new market reality.

\section{Concept and application of personal marketing techniques}

Personal marketing has been gaining more and more space in the most diverse areas of human activity, contributing to personal and professional growth in the job market and in the most diverse contexts (TASCIN et al., 2005). It is considered a marketing compound, used to generate attention, interest and preference towards a particular person, which in personal marketing, represents the product (LIMEIRA, 2004). Especially when used as a tool for enhancing skills and abilities, it can strengthen one's networks and status in the workplace, favoring the consolidation of spaces in this increasingly competitive universe (TASCIN et al., 2005).

This important development of marketing uses its tools to benefit the career and personal experiences of individuals, valuing the human being in all its attributes, structure and characteristics (KOTLER, 2000).

When we say that personal marketing promotes personal and professional growth, we are referring to the fact that by using it, one begins to seek the improvement of one's talents and skills by updating specific and general knowledge, and with it can more easily accomplish its goals and objectives. (TASCIN et al., 2005).

For Vaz (1995), the main goal of personal marketing is a success, or rather, to stand out from competitors and reach a prominent position. Personal marketing refers to the professional's ego, which wants the public to see where and when their action or presence is needed to solve problems or satisfy consumers' wishes. It is indispensable for veterinarians, not only for those who are present in clinics and pet shops but also for the self-employed professional working in the field (POLIZEL, 2019).

This type of marketing is aimed at the person so that their image is consolidated and become a heritage, but it must be borne in mind that people demonstrate inconsistencies of wants and needs that can complicate any effort to transform them and build their image (CONTURSI, 2008). According to Rosa (2004), a negative image can limit the person's opportunities, so one must be careful with the image and try to eliminate from it any item that may have an unfavorable impact. Thus, personal marketing is gaining more and more evidence, so that creating a personal brand is taught in many American universities and has been gaining ground in some institutions in Brazil (TASCIN, 2005)

For Rizzo (2011), there is confusion as to the interpretation of what personal marketing is, which often comes to be understood as advertising, selling, social etiquette, persuasion techniques. People often associate personal marketing with dress, posture, speech, but the concept of personal marketing goes beyond that, as it is essential to interact with others to achieve professional advancement (RAMALHO, 2008).

According to Carvalhal (2005), personal marketing is an expression that refers to the skills and incompetence of the individual, being three the main areas that can be worked by personal marketing: knowledge, skills and attitudes. The professional should show humility to ask for advice and ask questions, should have empathy and good humor, understanding and cordiality, help with problem-solving, listen 
carefully and show interest, expressing friendly, among other attitudes (PINHEIRO et al., 2005). Attitudes correspond to the values and beliefs that are formed and acquired throughout life. Knowledge is the set of information that the individual acquires and articulates when and how they need it. The skills correspond to the ability to put the acquired knowledge into practice to generate the desired results (CARVALHAL, 2005).

The central concept of marketing is exchange, while that of personal marketing is transformation. Personal marketing analyzes the image and characteristics that the individual possesses and what the sector wants and promotes the necessary transformations to bring the two sides closer together and, in this way, the exchange happens. Image transformation promotes changes in attitudes, habits, behavior, values and desires (KOTLER, 2000)

In practice, the general marketing compound consists of the so-called 4 P's, product, price, promotion and plaza. In the case of personal marketing, they are aimed at the individual (COBRA, 1997). For Cobra (1997) and Rizo (2011), in personal marketing the person represents the product, presenting all the elements that compose it in a metaphorical sense, such as the packaging and design of the product. Rizzo (2011) makes a comparison between the product packaging, which according to it is intended to protect and give visibility to the product, with the packaging of the product person. It states that in reality, the human being, when dressing, chooses how he will be performing in his day to day life. He points out that dressing according to one's function and working environment is special care, where one should avoid the use of extravagance, always prevailing common sense. The work of image, personal posture, and in some cases culture, customs and etiquette for certain situations and places is of utmost importance (PASSOS et al., 1999).

The price is closely linked to the value of ideas, competence, quality of work and the image that the professional represents (RIZO, 2011). The price depends on the appreciation, competence, credibility of the individual and is related to the attitudes, skills and knowledge of the professional. In personal marketing the price is the value paid by the market for the individual to carry out his tasks, in other words, how much it is worth to the market, this value being translated by his salary (BORDIN, 2006). The better the person knows how to do his personal marketing, the greater will be his market value (CORTEZ, 2012).

According to Kotler (1998), promotion for personal marketing is the way a person puts himself in the spotlight and is thus an impersonal means of communication. Promotion is the most interesting part of personal marketing work, but it is considered the most difficult part to do. Before starting to work on the promotion, it is first necessary to define what image the professional wants to pass on to the market (MANSUR, 1998). Rizzo (2011) states that when elements such as behavior and argumentation are in evidence, they first provoke a certain attraction and convey satisfaction in the company of the person. Still according to the author, the behavior needs to be frequently observed and stoned in order to be in accordance with social values. Mansur (1998) points out that the best-known promotion tool is advertising, which can be defined as any form of presentation to promote ideas, goods or services. Another important tool is public relations. Good examples of this are seminars, conventions, and other events where the practitioner can broaden their network and be seen and remembered by others, as well as the practitioner's participation in the activities of the community in which it operates (MANSUR, 1998; RIZZO, 2011). The 
professional should attend events, congresses, seminars and lectures, not only as a listener, but also expose their ideas, as these are great opportunities to meet new people thus increasing their network of contacts, their visibility and credibility. In addition, the professional must have the ability to develop good relationships in the workplace (PINHEIRO et al., 2005). In this item the credibility that has been gained over time through word of mouth makes a huge difference (MANSUR, 1998).

According to Ballback et al. (1999), the concept of square in personal marketing refers to the ways that professionals will make themselves available to those who want to buy their skills. In this regard, besides defining what services the individual will provide, one must also know how the service will be offered to the potential market. The individual must then define in which market or industry he is willing to operate and offer his services (MANSUR, 1998). The longer the individual's coexistence and friendship cycle, the more chances they will have to appear in the market, empowering the results. (SANTOS, 2002; BORDIN, 2006). Rizzo (2011) points out that the main point of personal marketing is selling and who does it most often is the person himself.

For the correct application of personal marketing techniques it is essential that the individual knows their strengths (BORDIN, 2006). The individual must remain in constant development and seek differentials to stand out (RIZZO, 2011). The Professional should maximize their qualities and use them to their advantage and look for organizations where those qualities are well applied and harnessed. The author also states that it is very important for the professional to know their weaknesses, because they are the ones that can harm professionals at some point in their career (BORDIN, 2006).

The educational improvement of the individual is essential to ensure their professional growth and survival in the job market. It is very important to attend lato sensu courses, master other languages, keep up with technological innovations in order to establish a successful career (SANTOS, 2002). Bordin (2006) emphasizes that committed professionals should always seek to remain above average when it comes to academic background and specific knowledge in relation to their competitors. According to Ribeiro (2005), today, the knowledge has become the main differential, thus being a determining factor in the market in which the professional operates.

The individual must be aware that it is a product exposed in the labor market, so it becomes more understandable what needs to be done to be desired and get a good acceptance. Therefore, the person needs to be clear what will sell to the market (PETERS, 2000; SANTOS, 2002). Personal marketing is seen as a marketing tool that drives professionals to work and awaken their talents and skills, thus increasing the chances of professional success in their field (VARGAS-MONIZ et al., 2011). In a world of innovation and almost predatory competition, the strategy is to know how to sell yourself well, emphasizing the product, in this case the person himself, object of negotiation (RIZO, 1998).

Personal marketing will can transform a life, but success is formed through work and attitudes, in other words, it is a story composed of victories and defeats, with some basic points that need to be considered for building success, because they are intimately linked to the individual (BAMBERG, 2000). 


\section{Marketing in Service Delivery}

Services are cost-effective activities that create value and provide customer benefits at specific times and places as a result of making a desired change in or on behalf of the service recipient (LOVELOCK, 2001). They can be considered as acts, actions and performance, being present in any business relationship (LAS CASAS, 2008). They have intangibility, inseparability, variability and perishability as particular characteristics (ARMSTRONG et al., 2007). Service marketing is worked differently than product marketing, this is because services cannot be seen, felt, heard, smelled or tasted (KELLER et al., 2006).

The Intangibility refers to the fact that unlike products, the service is not tangible, cannot be tasted or even seen before it is consumed, so this is the feature that makes service marketing more difficult to handle. worked that product marketing (ARMSTRONG et al., 2007). The Inseparability refers to the fact that services are normally consumed at the same time as they are being produced, while variability is present because the service is dependent on where it is offered and on whom it is offered (KOTTLER, 2006). Finally, the services may still be considered perishable as they cannot be stored and transported for later sale (KATHALIAN, 2002).

Due to its particularities, service marketing presents besides the tactical elements worked in the product mix, which are, product, price, square and promotion, plus 4 other P's, which are: the processes, the people, the profile and the productivity or quality (LAS CASAS, 2008).

For Las Casas (2008), "the product is the palpable, tangible part of the service, and organizations should be concerned with formulating a strong and competitive brand". In service, the price is viewed by the customer as a way to measure the quality of service (KELLER et al., 2006). For this reason, the price of services should not be stipulated in any way, being careful not to generate erroneous expectations on the client (LAS CASAS, 2008). The purpose of the square in the services is the same given in relation to the products, that is, to position itself better in the target market, but as the services have the characteristic of inseparability, the distribution points become shorter and consequently smaller range (KAHTALIAN, 2002).

In service marketing, the promotion is worked through sales promotion, personal sales, public relations and merchandising (COBRA, 2005). The sales promotion refers to the professional's participation in events that promote the company's image. The Personal selling is the direct contact with the customer provided by the service, enabling clarification about it, making the customer generate the proper expectations about the service being offered to him (LAS CASAS, 2008). The Public relations aims to get the cooperation of people with whom the entity relates and merchandising is a set of tactical operations performed, at the point of sale, to place the right product or service in the right amount, in right price, at the right time, with the right visual impact and the right exposure (COBRA, 2007).

People are one of the most important elements of service delivery because of their variability, that is, the quality of service may change depending on who provides it and how, when, where and how it is provided (ARMSTRONG et al., 2007). For Rizzo (2011) for the service provider, a good appearance is indispensable, and the professional must also adopt a formal posture and be straightforward in the answers, 
because the client's time is important and valuable. For Daronco (2011), "the image and attitude of people in personal marketing are of fundamental importance, because they explain the characteristics of the product, that is, of the person". Padilha (1999) points out that appearance is a fundamental aspect when it comes to the pursuit of personal success.

The processes are relevant because they reflect the performance of the service and should seek to identify all points of interaction that a customer has with the organization that make a good or bad impression (LAS CASAS, 2008). The profile concerns the environment in which the service is delivered and any tangible asset that facilitates the performance and communication of the service (ARMSTRONG et al., 2007). Finally, productivity is seen as efficiency, being achieved by optimizing the use of resources employed in order to maximize the desired results, that is, aims to optimize the quality of service (KELLER et al., 2006). For Las Casas (2008), quality of service is measured through customer satisfaction.

According to Keller et al. (2006) there are five determinants of service quality: the reliability, the responsiveness, the security, the empathy and the intangibility. The Reliability is about making customers receive the service as promised, without feeling harmed by the company (LAS CASAS, 2008). Responsiveness refers to the company, in the person of the professional who serves it, being able to respond to customer requests (KELLER et al., 2006). The security occurs when customers feel safe with their choice (LAS CASAS, 2008). Now, the empathy is defined as a friendship, a care, an individual attention given to the client (KELLER at al., 2006).

To service providers should focus on quality. What the customer is looking for when buying a service is quality service. The client wants to feel safe and confident that it has made the right decision when choosing that professional, when it is sure of that, ends up being loyal to the company. It is also of utmost importance that the system designed to support this mission be properly controlled (BATESON et al., 2003).

\section{The veterinarian as a service provider and personal marketing as a differentiator}

The Veterinarian usually acts as a freelance professional self-service provider, in addition to his technical duties, in most cases also plays the role of business administrator (HELLMEISTER, 2006). When providing services, it is necessary to have professional competence, so that it can be perceived in a rewarding way within the competitive market (FLOSI, 2001). The products and services offered meet competitors that are similar in both price and performance, it is not enough for the professional service provider to have all the knowledge about them if they cannot communicate effectively with their customers (GIOSO, 2007).

The service sector is dynamic and constantly undergoing renovations, especially new ventures, offering new service standards where competitors already established in the market have failed to meet customer demands (LOVELOCK et al., 2005). The competence and specialization of the veterinarian makes the establishment grow and generate more sales, making the most important of a product is the service provided by him (FLOSI, 2001).

According to Kotler (2002), service providers have gradually discovered that any professional, whether lawyer, accountant, doctor or veterinarian, can perform marketing with professionalism in their 
work routine. To transform a clinic or veterinary care into a profitable business requires a technical ability and respect for professional ethics (POLIZEL et al., 2019). For Peters (2000), personal marketing in these cases represents "the individual ability to attract and maintain personal and professional relationships among the team, with customers, with managers, directors, among others permanently so that through and through them perform cycles of meeting mutual needs, generating satisfaction for all".

For health professionals, the marketing is still very little used, especially due to the lack of knowledge of its meaning and application. The marketing is a fundamental tool to help market any company or professional. Ensures your stay in the market is well executed. So, the marketing should not be restricted to being used only by companies, but should also be part of the formation and image of health professionals (FLOSI, 2001). According to Peters (2000), "today, the most important for those who want to work and do business, is to be the director of brand marketing called you".

The big problem is the acceptance of the idea that marketing is a necessary tool that helps to diagnose and modify the situation in the veterinary establishment. However, this action cannot be isolated, but can be part of a set of solutions aimed at improving the productivity and performance of the veterinary business (LOBATO, 2006).

The marketing has the function of assisting the veterinary market, guiding and adjusting processes, training company members, creating opportunities and planning the steps for the business to become a center of productive decisions (LOBATO, 2013). According to Flosi (2001), "a fundamental aspect that is part of the personal mark of the Veterinary Medicine professional is health. Both in terms of personal marketing and quality of life it is essential to be healthy, as this is one of the factors in the first-hand process of building your personal brand". For the author, the veterinarian should be concerned not only with obtaining technical knowledge about his profession, increasing his professional qualification, but also taking care of his image, seeking to maintain a posture inside and outside the work environment, improving communicating with colleagues and clients, being punctual and being a health professional working even more in their daily lives the ability to provide humane and empathic care.

\section{The influence of the veterinarian on the purchase process}

The Veterinarian usually acts as a liberal professional, technical service provider (FLOSI, 2001). What differentiates a liberal professional from other professionals is mainly their technical knowledge, which includes the scientific and/or manual knowledge of each profession. This technical knowledge must be certified by a professional degree, conferred by an authorized higher education school (SARAIVA, 1941).

A few years ago, there was a high tendency on the part of liberal professionals, as veterinarians, engineers and lawyers, not to consider themselves sellers of the services and products they offer, adopting defensive and prejudiced postures regarding the application of marketing concepts in their professional routine, even considering them as unethical conduct in some cases. (GIOSO, 2007). Currently, the veterinarian begins to recognize himself as part of a chain in which his knowledge is essential to influence a buying and selling process (GIOSO, 2007). As consumers of these products and services become more 
demanding and interested in information, the professional able to transmit this knowledge will surely succeed in this ultra-competitive market (GIOSO, 2007).

The veterinarian is the only professional trained to develop and apply animal health and welfare programs, adapting them to the customer profile and adapting them individually to each patient (PEREIRA, 2003). In the distribution chain, the veterinarian positions himself with fundamental importance as a purchasing influencing role, considering very peculiar characteristics of his profession (FLOSI, 2001).

The veterinarian then needs to follow some rules to produce and use professional services marketing, starting with planning, establishing mission, purpose, organizing, checking costs, pursuing profit following ethics, obtaining knowledge that differentiates it from the competition (courses diversification) and to diversify product and service offerings (FLOSI, 2001). Thus, it is essential to know and apply marketing techniques as a differential to be offered to the customer (GIOSO, 2007).

\section{CONCLUSIONS}

Increasingly, the interaction of families with their pets is changing, now these animals are now considered members of the family. This worldwide change in society makes the pet market constantly rising. In Brazil, for several consecutive years, is among the largest world markets in the area.

In addition to the considerable increase in the number of veterinary clinics and pet shops in the country, which makes the market increasingly competitive, pet owners are increasingly demanding not only for good products but also for services differentiated veterinarians in order to provide the best quality of life for these new members of their families.

The Veterinarians are of great importance in the pet market and, therefore, must adapt to this new reality, being concerned not only with technical training, but also with awareness of their role in the market and seeking to invest in marketing techniques that increase your personal and professional visibility. The undergraduate courses in Veterinary Medicine, in general, do not prepare the professional in this sense, so as part of their training for the job market, the veterinarian should seek to study, know and apply marketing techniques, especially personal marketing to gain visibility, build customer loyalty, differing from other professionals.

The professional who knows how to use personal marketing has much more chances to achieve success, he will know how to analyze all situations, thus reducing the chance of making mistakes, will know how to conduct his establishment in a correct and productive way, and will know how to promote himself.

\section{REFERENCES}

ANDERLINE, G. P. O. S.; ANDERLINE, G. A.. Benefícios do envolvimento do animal de companhia (cão e gato), na terapia, na socialização e bem-estar das pessoas e o papel do médico veterinário. Revista do Conselho Federal de Medicina Veterinária, Brasília, v.13, n.41, p.70-75, 2007.

ARMSTRONG, G.; KOTTLER, P.. Princípios de marketing. 12 ed. São Paulo: Pearson, 2007.
BALLBACK, J.; SLATTER, J.. Marketing pessoal: como orientar sua carreira para o sucesso. 3 ed. São Paulo: Futura, 1999.

BAMBERG, M.. Estourando a ponte: marketing como instrumento de valorização pessoal e profissional. 3 ed. São Paulo: Kelter, 2000. 
BATESON, J. E. G; HOFFMAN, K. D.. Princípios de Marketing de Serviços: Conceitos, Estratégias e Casos. São Paulo: Pioneira Thomson Learning, 2003.

BORDIN, S.. Marketing Pessoal: 100 Dicas para valorizar sua imagem. 12 ed. Rio de Janeiro: Record, 2006.

CANAL, I. H.; CANAL, R. B.; OLIVEIRA, R.. SEM - Sistema de Estoque Mínimo - QP-PP - Quantidade a Pedir - Ponto a Pedir. Revista Nosso Clínico, São Paulo, v.50, n.9, p.12-17, 2006.

CARVALHAL, D.. Marketing Pessoal. Revista da Fundação Visconde de Cairu. Salvador. v.6, n.12, p.111-126, 2005.

COBRA, M. H. N.. Administração de marketing no Brasil. 4 ed. São Paulo: Cobra, 2014.

COBRA, M. H. N.. Marketing básico: uma abordagem brasileira. 4 ed. São Paulo: Atlas. 1997.

CONTURSI, E. B.. Marketing esportivo. 2 ed. Rio de Janeiro: Sprint, 2000.

DIEHL, A. A.; TATIM, D. C.. Pesquisa em ciências sociais aplicadas: métodos e técnicas. São Paulo: Pearson Prentice Hall, 2006.

ELIZEIRE, M. B.. Expansão do mercado Pet e a importância do Marketing na medicina veterinária. Monografia (Graduação em Medicina Veterinária) - Universidade Federal do Rio Grande do Sul, Porto Alegre, 2013.

FARACO, C. B.; SEMINOTTI, N.. A relação homem-animal e a prática veterinária. Revista do Conselho Federal de Medicina Veterinária, Brasília, v.10, n.32, p.57-61, 2004.

FLOSI, F.. Marketing na Veterinária. 2 ed. São Paulo: Varela, 2001.

FUCK, E. J.; FUCK, E. T.; DELARISSA, F.; CURT, C. E.. Relação Homem X Animal Aspectos psicológicos e comportamentais. Revista Nosso Clínico, São Paulo, v.9, n.49, p.46-58, 2006.

GIOSO, M. A.. Profissional Liberal: Como ganhar mais dinheiro de forma ética. São Paulo: MedVet, 2007.

HAGIWARA, M.. Mitika Hagiwara: testemunha ocular. Revista do Conselho Regional de Medicina Veterinária de São Paulo, São Paulo, v.22, n.60, p.10-13, 2015.

KELLER, K. L.; KOTTLER, P.. Administração de marketing. 12 ed. São Paulo: Pearson, 2006.

KOCHE, J. C.. Fundamentos de metodologia científica: teoria da ciência e prática da pesquisa. 15 ed. Rio de Janeiro: Vozes, 1997.

KOTLER, P.. Administração de marketing: a edição do novo milênio. São Paulo: Pearson Prentice Hall, 2000.

KOTLER, P.. Administração de marketing: análise, planejamento, implementação e controle. 5 ed. São Paulo: Atlas, 1998.
KOTLER, P; KELLER, K. L.. Administração de marketing: a bíblia do marketing. 12 ed. São Paulo: Pearson Prentice Hall, 2006.

LAKATOS, E. M.; MARCONI, M. A.. Fundamentos de metodologia científica. 7 ed. São Paulo: Atlas, 2010.

LIMEIRA, T. M. V.. Gestão de Marketing. São Paulo: Saraiva, 2004.

LOBATO, S.. Manual de Responsabilidade técnica para clínicas veterinárias e pet shops. Rio de Janeiro: L. F. Livros, 2006.

LOVELOCK, C. H.; WRIGHT, L.. Serviços: marketing e gestão. 2 ed. São Paulo: Saraiva, 2005.

MANSUR, M.. Marketing pessoal passo a passo. Belo Horizonte: Autêntica, 1998.

MARCONI, M. A.; LAKATOS, E. M.. Técnicas de Pesquisa: planejamento e execução de pesquisas, amostragens e técnicas de pesquisa, elaboração, análise e interpretação de dados. 5 ed. São Paulo: Atlas, 2002.

PADILHA, E.. Marketing pessoal e Imagem pública. 4 ed. Curitiba: Pallotti, 1999.

PASSOS, A.; NAJJAR, E. R.. Carreira e marketing pessoal: da teoria à prática. 2 ed. São Paulo: Negócios, 1999.

PENTEADO FILHO, J. R. W.. Marketing no Brasil não é fácil. 3 ed. Rio de Janeiro: Livro Técnico e Científico, 1990.

PETERS, T.. Reinventando o trabalho: A marca você. 3 ed. São Paulo: Campus, 2000.

PINHEIRO, A.; SALES NETO, F. L.; BARBOSA, M.. A utilização do marketing pessoal pelos advogados de Salvador. Monografia (Especialização em Administração) Universidade Federal da Bahia, Salvador, 2005.

POLIZEL, F. F.; LEONI, J. N.. Marketing em Medicina Veterinária. Revista Empreenda Unitoledo, São Paulo, v.3, n.1, p.194-212, 2019.

RAMALHO, R. J.. Você é sua melhor marca: Como o marketing pessoal pode ser utilizado para fazer a diferença em sua carreira. Rio de Janeiro: Elsevier, 2007.

RIBEIRO, A. L.. Gestão de pessoas. 7 ed. São Paulo: Saraiva, 2005.

RIZZO, C.. Marketing pessoal, relacionamento e neolinguística: instrumento para negociação. 2 ed. São Paulo: Terra, 1998

SANDHUSEN, R. L.. Marketing básico. 2 ed. São Paulo: Saraiva, 2003.

SANTOS, D. S.; SILVA, M. M. P.. A importância do marketing empresarial para micro e pequenas empresas. Revista Facima Digital, Maceió, v.1, n.1, p.29-44, 2016.

SHAW, E. H.; JONES, D. G. B.. A History of Schools of Marketing Thought. Marketing Theory, London, v.5, n.3, 
p.239-281, 2005. DOI:

http://dx.doi.org/10.1177/1470593105054898

SOUZA, M. C. B. B.. Médico Veterinário: que profissional é esse. Revista do Conselho Federal de Medicina Veterinária, Brasília, v.2, n.6, p.11, 1996.

TASCIN, J. C.; SERVIDONI, R.. Marketing pessoal: uma ferramenta para o sucesso. Revista Científica Eletrônica de Administração, São Paulo, v.5, n.9, 2005.

TATIBANA, L. S.; COSTA-VAL, A. P.. Relação homem-animal de companhia e o papel do médico veterinário. Revista Veterinária e Zootecnia em Minas, Belo Horizonte, v.28, n.103, p.12-18, 2009.
VARGO, S. L.; LUSCH, R. F.. Evolving to a new dominant logic for marketing. Journal of Marketing, Washington, v.68, n.1, p.1-17, 2004. DOI:

https://doi.org/10.1509/jmkg.68.1.1.24036

VAZ, G. N.. Marketing Institucional: O mercado de Ideias e Imagens. São Paulo: Pioneira, 1995.

YOUNG, M. S.. The evolution of domestic pets and companion animals. Veterinary Clinics of North America: Small Animal Practice, Philadelphia, v.15, n.2, p.297, 1985. DOI: https://doi.org/10.1016/S0195-5616(85)50302-2

ZALTMAN, G.; PARK. C. W.. Marketing management. Chicago: Dyden Press, 1987.

A CBPC - Companhia Brasileira de Produção Científica (CNPJ: 11.221.422/0001-03) detém os direitos materiais desta publicação. Os direitos referem-se à publicação do trabalho em qualquer parte do mundo, incluindo os direitos às renovações, expansões e disseminações da contribuição, bem como outros direitos subsidiários. Todos os trabalhos publicados eletronicamente poderão posteriormente ser publicados em coletâneas impressas sob coordenação da Sustenere Publishing, da Companhia Brasileira de Produção Científica e seus parceiros autorizados. Os (as) autores (as) preservam os direitos autorais, mas não têm permissão para a publicação da contribuição em outro meio, impresso ou digital, em português ou em tradução. 